\title{
Practitioner Action Research for Studying Higher Education and Improving the Quality of Teaching
}

\author{
TONY HARLAND \\ University of Otago, New Zealand \\ (tony.harland@otago.ac.nz)
}

\begin{abstract}
There is increasing interest in the quality of university teaching and how academics learn to be teachers. This paper examines the idea of empowering academics as researchers of their own teaching practices so they not only learn about that practice, but also make a commitment to knowledge for the wider teaching community and contribute to the theories of higher education. The arguments draw on the historical context of influences on professional learning and what can be understood from the changing conceptions of working practices in our universities. The paper concludes with some reflections on the current Malaysian situation where the idea of practitioner research for university lecturers is currently being explored.
\end{abstract}

\section{INTRODUCTION}

This article explores the idea that professional development for university teaching is best done by teachers as researchers of their own practices and that such development can and should contribute to mainstream higher education research and the wider academic community. This paper proposes a type of practitioner action research that not only brings about teacher learning but also seeks to be part of a wider research field. At present, researching the subject of one's practice stubbornly remains on the fringes of legitimate academic activity and it will be argued that we can normalise this through a closer alignment of practitioner action research with the established research disciplines. However, this will require additional commitment from those who select this mode of professional learning. Obligations will include: 1) making inquiries public and opening these up to the scrutiny of peers, 2) focusing not only on the researchers' own learning but making conscious 
and systematic efforts to help others, and 3) recognising that the teacher as researcher should aim to become active in the existing community of scholars and in doing so contribute to the study of higher education. Making such a contribution requires high quality practitioner research.

To examine these ideas a historical approach is taken to look at some of the milestones that have influenced how we currently practice teaching in higher education and then build a case for action research as a mode for learning about teaching and for learning about research in a new field. The paper will conclude with some observations on the current Malaysian higher education situation where the central ideas to my argument are currently being played out across a diverse university and tertiary education sector.

\section{Milestones in Higher Education}

It is worth starting with the fact that higher education teaching is almost entirely an amateur occupation. The teacher 'training' required of most university lecturers is either three to five years of learning how to do research, or the practical and professional knowledge and skills they bring from the workplace outside academia. Lecturers then learn about teaching through trial and error and for some, a gradual ad hoc process of academic development as they attend occasional workshops or courses on teaching. Tenure processes may address the quality of an individual's teaching performance in the longer term but it still seems astonishing that someone can be employed to teach at a university without any experience or training whatsoever. Such a situation may have been more acceptable during the elite era of the university in which very bright students were carefully selected and were likely to learn independently of the quality of teaching, but the worldwide move to mass-higher education and the wider access this gives to students of differing abilities requires new teaching expertise if all students are to reach their potential.

The university lecturer needs to understand how such a situation has come about and five points in recent history were identified that have been influential in shaping the way we think and value teaching in higher education. This section begins with the formation of the modern research university in the nineteenth century and the separation of research and teaching as different and competing roles in academic life. This is followed by a look at John Dewey's unifying theory of inquiry that explains how the process 
of knowledge formation is similar in both scientific and practical contexts. As such, the process of inquiry contests the logic of the research-teaching divide and provides the academic community with a foundation for understanding professional learning as a form of research. From Dewey, the action research movement of the 1940's and then two seminal ideas that have become the foundation of professional development for teaching are revealed. These are Donald Schön's reflective practitioner and Ernst Boyer's teacherscholar. In the table below the five milestones are summarised:

\section{Table 1}

Milestones in the Epistemology of Professional Learning in Higher Education

\begin{tabular}{|c|c|c|c|}
\hline Important events & Period & Epistemology & $\begin{array}{l}\text { Impact on learning about } \\
\text { teaching }\end{array}$ \\
\hline $\begin{array}{l}\text { Humboldt's } \\
\text { foundation for the } \\
\text { modern research } \\
\text { university }\end{array}$ & 1800’s & $\begin{array}{l}\text { Technical rationality } \\
\text { of the natural sciences } \\
\text { central to knowing }\end{array}$ & $\begin{array}{l}\text { Research and teaching } \\
\text { separated, theoretical } \\
\text { knowledge given to and } \\
\text { applied by professionals }\end{array}$ \\
\hline $\begin{array}{l}\text { Dewey's philosophy } \\
\text { of inquiry }\end{array}$ & 1900’s & $\begin{array}{l}\text { Inquiry to replace } \\
\text { epistemological } \\
\text { dualism inherent } \\
\text { in divide between } \\
\text { theoretical and } \\
\text { practical knowledge }\end{array}$ & $\begin{array}{l}\text { Science and professional } \\
\text { learning unified and } \\
\text { legitimised through the } \\
\text { same inquiry processes }\end{array}$ \\
\hline $\begin{array}{l}\text { Lewin's Action } \\
\text { Research }\end{array}$ & 1940’s & $\begin{array}{l}\text { Introduces the idea } \\
\text { of action research } \\
\text { to sit alongside the } \\
\text { technical-rational view }\end{array}$ & $\begin{array}{l}\text { Empowering the } \\
\text { professional as inquirer, } \\
\text { introducing the action } \\
\text { research spiral as } \\
\text { naturalistic inquiry }\end{array}$ \\
\hline \multirow[t]{2}{*}{$\begin{array}{l}\text { Schön's Reflective } \\
\text { Practitioner }\end{array}$} & \multirow[t]{2}{*}{1980 ’s } & $\begin{array}{l}\text { How professionals } \\
\text { think and act }\end{array}$ & $\begin{array}{l}\text { A theory for professional } \\
\text { development that } \\
\text { re-formulates Action }\end{array}$ \\
\hline & & Knowing in action & $\begin{array}{l}\text { Research and Inquiry } \\
\text { through the Reflective } \\
\text { Practitioner }\end{array}$ \\
\hline $\begin{array}{l}\text { Boyer's Scholarship } \\
\text { Reconsidered }\end{array}$ & 1990’s & $\begin{array}{l}\text { Teaching becomes } \\
\text { a scholarly activity } \\
\text { analogous to research }\end{array}$ & $\begin{array}{l}\text { Enhancing the status of } \\
\text { teaching and a new focus } \\
\text { on addressing social } \\
\text { change }\end{array}$ \\
\hline
\end{tabular}

The modern research university is often attributed to 19th century Germany and the philosophy of Wilhelm von Humboldt. In this radically new conception of a higher education, the key function became the pursuit of knowledge though research and this legacy 
now manifests itself in the current scientific university that produces knowledge and educates students, with each of these products compartmentalised (Barnett, 1990). Research is now a separated activity and it has become valued above all else. The parting of research is embodied in the paradigm of technical rationality and so when it comes to learning about teaching, knowledge is produced by educational researchers and then handed to lecturers for them to apply in their classrooms.

This expert tradition tends to create a theory-practice gap, especially for those who understand theory in the scientific sense or require knowledge concepts that are generalizable in similar situations (Carr \& Kemmis, 1986). Dewey (1910) rejected such dualistic thinking and sought to challenge the distinction between theoretical and practical knowledge by proposing that the process of inquiry was the same in either construct and so could provide a unifying concept for practice (Dewey, 1938). Dewey claimed that the properties of inquiry are contained in thinking and action, and the patterns of inquiry are the same for all epistemological conceptions. It does not matter if the inquirer is addressing a question in science or a problem of everyday professional practice; knowledge is formed through the inquiry process.

The third milestone of note is Kurt Lewin's recognition of the need to legitimise the construction of practical knowledge for professional learning. Lewin developed the concept of action research which is essentially a problem-based approach to professional learning (Lewin, 1946). A practitioner identifies a problem that needs a solution and then embarks upon a process of problem identification, imagining possible solutions, trying these out, systematically evaluating the outcomes, and embedding change in practice. Often the steps of observation, data gathering, reflection, and change are cyclical. Such a method results on actionable theories and contrasts with the view that teachers should apply the theories that educational experts have developed for them. Lewin, however, appeared to have taken a utilitarian stance that differs from Dewey by accepting that practical and scientific epistemologies should work alongside each other. He is clear, however, that for either type of research to have any utility, the forms of knowledge they produce need to be integrated in practice: "research that produces nothing but books will not suffice" (p. 35).

In the 1980's Donald Schön explicitly re-worked Dewey's principles of inquiry and the concept of action research for professional learning, and developed his theories of reflective 
practice. In doing so, these older theories were made much more accessible to those who work in contemporary higher education institutions. In fact, his ideas are foundational to the majority of the initiatives we have today that have been designed to enhance teaching. Learning to teach is almost synonymous with reflection on and in practice, and the idea of the reflective practitioner is now well established (Schön, 1987, 1992, 1995). For example, the teaching portfolio (Seldin, 2004), peer review of teaching and the professional standards movement (e.g. in the UK the Higher Education Academy's Professional Standards Framework, UKPSF) have a foundation in reflective practice.

Schön was interested in competence and how professionals become excellent practitioners. He suggested that we have espoused theories that we use to explain our behaviour and also tacitly held theories-in-use which are only implicit in our behaviours. The reflective practitioner focuses on bringing tacit theoriesin-use into the espoused domain, and for teachers, this means systematically examining their own teaching experiences and the technical competencies, values and knowledge that underpin these. The type of reflective activity Schön promotes is not routine and requires a clear rationale. In universities the stimulus is typically the requirement to prove competency in teaching. However, it should also be noted that if we accept Dewey's proposition, focused and systematic reflection is also a component of any research inquiry, including action research.

The theories of Dewey, Lewin and Schön appeared to have had little influence on the functional separation of teaching and research or the subsequent practice disparities that became a feature of higher education in the 1980s and that continue today. The Scholarship of Teaching and Learning (SoTL), however, specifically sought to re-dress the imbalance between teaching and research through enhancing the status of teaching (Boyer, 1990). Ernest Boyer, who was President of the Carnegie Foundation for the Advancement of Teaching, proposed that teaching should be reconsidered in four dimensions that he described as scholarly. These were the scholarships of discovery, integration, application, and teaching. Discovery is about research; integration about utilising existing theory; application the process of applying knowledge, and teaching as the process of teaching.

The SoTL movement, however, never gained much ground in higher education although the concept is still current, probably because of the status of Carnegie, Boyer and his colleagues. The 
problem seems to be that the concept is difficult to understand and largely unworkable as a practical idea. In a critique of SoTL, Boshier (2009) explained why these difficulties occur. Firstly, for operational purposes SoTL is understood as a disaggregated approach with each element as a separate activity when in fact there is much overlap between them. Secondly, teaching should have been the context for discovery, integration, and application: "how could the scholarship of teaching be one quarter of the scholarship of teaching?" (p. 5). Thirdly, providing evidence of applying the four dimensions of SoTL in accountability exercises, such as tenure, has proved to be very difficult and it is equally hard to evaluate the impact of SoTL on the learner.

So with all its short-comings, why mention SoTL in this account? Firstly Boyer brought us full circle to the values and ideals of the enlightenment project in which the scholar was neither researcher nor teacher, but undertook these activities in a more holistic practice. In contrast, today it is usual to talk of research and scholarship as if research was something separate. Secondly, the scholar is expected to think more about the various functions of a higher education and the wider social implications of teaching. Third, and for the purposes of this argument, Boyer's concept of integration is a way of explaining how we can bring existing theoretical knowledge into our professional inquiries about practice and, in turn, allow us to contribute quality action research to the wider store of knowledge in the field of higher education.

Although both these forms of integration are essential, the teacher-researcher also needs to acknowledge that splitting teaching and research is reductionist, and genuinely gets in the way of explaining what actually goes on in academic practice. In order to reflect our lived experiences more accurately, there is a calling for a subtle conceptual shift towards inquiry and systematic practitioner research that enables teaching to be seen as a research activity and research as a teaching activity. Doing this allows new ways of thinking about professional learning that has utility for all facets of academic work.

\section{Teaching as Research and Research as Teaching}

A case can be made more generally for the seamless interchangeability of the terms teaching and research, even though in common usage and the way we typically experience these, there is 
clear-cut practical and conceptual separation. In fact, this paper will not even be able to make the case for correspondence in this argument without criticism because it too cannot avoid differentiating each term.

Although it is only in the more recent organisation of the university that academics experienced research and teaching as different activities, the last 20 years or so of neoliberal reform have rendered the split unconditional through the drive to make academics accountable for different work activities (Harland, 2009). Not all tasks are valued equally and in a competitive process some win out over others. Research is now valued above teaching and service, and academic prestige, career progression, institutional funding and position in world league tables typically depend on the quality of research.

The outcome for teaching is to re-enforce the compartmentalisation of knowledge production and knowledge dissemination. Scholars are either doing research or teaching in class even though this separation sits awkwardly within our academic communities and there are many who seek to bring these activities into closer alignment by attempting to add value to teaching with respect to research (Brew, 2010, Jenkins, Breen \& Lindray, 2003). However, it is suggested that this is unlikely to happen unless research becomes the foundation of teaching practice and that the outcome of such an inquiry strives to be of sufficient quality for the work to take its place alongside research in other disciplines.

What is required is an epistemological turn in which it is understood that research is and always has been a form of teaching and that teaching is a part of all genuine research. If research is defined as a systematic enquiry made public (Stenhouse, 1980) then the purpose of making public can only be that someone else can learn from the research. Therefore, publishing a research article in a journal or giving a research seminar are both forms of teaching (the outcome is that the reader or listener learns something). So for the academic who actively studies coral reef biology and teaches about coral reefs, everything they do requires that they teach because the ultimate purpose of all knowledge creating activities is to help others learn. It has also been widely argued that the benefit to the quality of learning is that the same academic is engaged in both knowledge production and dissemination, and there is a strong belief that the quality of teaching done by researchers is crucial to a higher education. This view is foundational to the research-intensive universities and unified university systems, for example, New 
Zealand's higher education sector which has research-led teaching as a statutory requirement.

Similarly, there is evidence that the teacher (as researcher) is best placed to research their own practices, rather than rely on knowledge from others (Harland and Staniforth, 2000). If they are engaged in a systematic inquiry into their practice and then make the outcomes of this inquiry public, perhaps through applying new knowledge in their classrooms or publishing a journal article, they too can claim they are doing research. The academic is both researcher and teacher although they now have a new subject and this is the study of their professional practice.

I would go further and suggest that we consider teaching as a subject in the same way we think of studying more traditional subjects like biology and chemistry. This practice focus is clearly recognised in many other branches of professional education and in all established university disciplines we find that a few teachers who research the pedagogy of that discipline, contribute to their own learning and publish their work to provide knowledge for their disciplinary teaching communities and sometimes for the wider academic community. We can therefore re-formulate Lewin's assertion by saying that research that produces both change and books is a better way forward in a contemporary higher education.

Academics who choose this path need to conduct their research in such a manner that the academy understands and legitimises their work. Doing so requires evidence that the research can meet the same criteria and standards of quality that are definitive of established disciplines. Of course we already know this is achievable because of those who attend higher education conferences and publish educational research in a range of high quality peer reviewed international journals and the study of higher education as part of the discipline of education, has a long history and rigorous academic standards that can ensure quality. Some may see this as their primary research focus while others may research first into the subject they teach and occasionally into the pedagogy of teaching that subject. Moreover, when practitioner research is aimed at improving teaching and done by the teacher as a researcher, the work can have immediate utility as new learning and knowledge quickly become part of their daily practice. This temporal immediacy is something that research in many other disciplines cannot achieve.

Barnett (2003), however, casted doubt that the wider adoption of teaching research as mainstream research is feasible. He contended that teaching as a focused inquiry project will not displace 
the dominance of established research disciplines and "to surround itself with the trappings of a research infrastructure" is a move to secure its own position which paradoxically is to surrender to "the ideology against which it contends" (p. 151). Scholars should not be troubled by this idea or the fact that research into teaching will not be counted in the same way as other forms of research. All research areas are compared with each other and all are valued differently, but the acid test for the acceptance of teaching-as-research is the same as any other research field, in that the outcomes of inquiry must be of quality, and this will be ultimately judged by the difference the work makes to knowledge and practice.

It is also suggested that most university teachers are inquirers in the first place and that natural curiosity, or established disciplinary research skills, can be systematically applied in many professional contexts. The researcher of coral reef biology is responsible for contributing to new knowledge in the coral reef field and then for teaching this, but they can use the same inquiry skills and their inquisitiveness to investigate teaching practices as a form of continuous professional development. In doing so they may also use their expanding critical proficiency to improve the quality of their coral reef research or even service activities. This conception of academic life is analogous to the more traditional idea of the scholar and the ideology of a liberal education. According to Anderson (1993) the aims of a liberal education are to enhance the powers of the mind:

\begin{abstract}
It is not only the 'results' of an inquiry - the facts and theories - that the university should teach. Rather the very object of inquiry should be to find out how thought can do better. (p. 59)
\end{abstract}

Anderson went on to talk about habits of mind, ways of thinking, and thinking clearly about all the affairs of everyday life, ideas which must apply to an academic's teaching practice as well as their disciplinary research and service.

In reality the concept of the liberal scholar applied in a modern context is fraught with difficulty as academics respond to pressures of compartmentalise work activities that are not equally valued. This systemic barrier requires an ontological turn with the teacherresearcher being prepared to make time for practice to become a genuine subject for study as they place themselves at the centre of the research process. They may recognise that inquiry is first an act 
of self-teaching but also need to accept that an additional step is necessary if Stenhouse's idea about research being made public is accepted. There is a well established argument that research-based action is a form of publication, e.g. improved classroom teaching practices as an outcome of inquiry (Stenhouse, 1981), but what is still valued above all else in our academic communities is publication of research accounts that have undergone peer review, in particular those that appear in journals and books.

So if the argument is accepted that the aim of disciplinary research is to teach ourselves and others, then we can achieve the same purpose when the teacher makes the subject of their teaching the focus of research. Learning about teaching practice done through research inquiry is likely to be genuinely educational for the teacher, however, it is also suggested that the teacher-researcher sets sights on written forms of publication because this will enhance the quality of thought, legitimise the activity within the academy, and allow a larger contribution to the teaching profession.

\section{AN ACTION RESEARCH METHOD}

In this context, improving teaching quality using action research can be done in such a way that it also has the potential to be published and contribute to the theories of higher education. The action research method has the great advantage of being simple and intuitive for teachers although not all will feel comfortable in a qualitative research paradigm or in understanding the close relationship between their educational practices and theory concepts. What may also seem daunting for the action researcher seeking to publish is how to confidently integrate older knowledge and theory into their own theories of practice, and then embed both in newly constructed research accounts.

Although it can take many years to become confident in a new knowledge area, the study of higher education (as the incumbent field) already publishes action research, typically as case-study work, and there is a range of specialist action-research journals to provide examples of what can be achieved. The international peer community assures the quality of this work but this essential measure can also create an initial barrier for someone new to practitioner research, regardless of any other research expertise they may have.

New researchers not only have to learn about relevant theory, but also how their inquiries can contribute to a theoretical body of knowledge and what counts can be hard to grasp. If the action 
researcher thinks of theory as a construct of personal practice, as Schön does, it can be seen that a teacher's own learning from experience and inquiry avoids any disparities between personal and scientific theories. What is foundational in action research is the teacher's own learning as they engage in a systematic data gathering process, and as a result, the change in the quality of professional practice. However, developing knowledge through action research in a community has more potential than personal research reflections enacted through changes in classroom practices. The private researcher misses out on the strength and rigour that comes from the collaborative processes of a self-critical community. Making research public serves to validate knowledge and then, if the work has been done well, it can be published and contribute to the wider knowledge project in the same way as any research activity.

\section{HIGHER EDUCATION LEADERSHIP ACADEMY(AKEPT)}

In 2008, the Malaysian Ministry of Higher Education established the Higher Education Leadership Academy (AKEPT) to develop innovative teaching and learning practices as part of a major sectorwide transformation (Konting, Singh, \& Idris, 2009). Part of this change was to encourage teaching practices based on action and conceptual research, and that this capacity would be developed within each institution and for all academics. It has been proposed that nationally recognised qualifications in teaching will have a research component and it is expected that research into higher education using teacher action research will lead to both enhanced practice and publication of articles in peer reviewed journals. Sectorwide research training based on this strategy began in 2009 .

The AKEPT initiative is remarkable in its vision but not without its challenges, not least because of the different levels of teaching expertise found within a highly diverse higher education sector. For the teacher without a disciplinary research background or research training, it is possible to undertake action research and quickly improve practice but it may take many years to develop this capacity to the standard necessary for the work to be published in a peer reviewed journal. It will, however, provide a research identity, new understanding of knowledge, and quickly improve teaching and learning practices. Mentoring from those more experienced in action research will be essential in this scheme and such a role may partially fall under the remit of the academic development 
community. However, in this context the academic developer must also have research experience to be a research mentor, and we know that in many universities around the world that this is not always the case (Harland \& Staniforth, 2009).

The teacher with disciplinary research expertise will already have skills to bring to practitioner research but can they be expected to love the subject of their own teaching as much as their disciplinary subject? If this does not happen, less interesting research into teaching may be seen as competing with the work done in the academic's first discipline. Perhaps we can at least hope that they will value it as a legitimate activity and apply their research skills and intellect to practice situations they are curious about, while recognising it as a powerful professional development tool. Boyer's idea of the scholarship of integration and Dewey's theory of inquiry come in to play here as the teacher-researcher will amalgamate inquiry-process skills in both fields and will naturally feel the need to integrate wider theories about practice.

\section{CONCLUSION}

Our current higher education systems recruit academics without expertise in teaching into a culture where academic practice is seen to consist of markedly different activities that are not all valued the same. Although some academics make excellent teachers from the day they enter a university, many more need to work hard at developing their knowledge and skills as they work out how to provide the best education for all their students. What is best will be judged by how the teacher understands the contested and complex purposes of higher education and whether or not they wish to realise these in their classrooms. For most, this task is a lifetime's inquiry.

The debate about the partitioning of research and teaching, and the demise of the liberal notion of scholarship is a common feature of academic life today. Dewey was very clear about rejecting such a dualistic concept but it is a problem that drives us on an endless quest to bring research and teaching back together. There is a strong belief that research-led teaching defines academic practice for a higher education, with the academic constructing and disseminating knowledge. This is also the model we use for our students' education with the student-as-researcher as the ultimate goal, especially in the elite research-intensive institutions. We now need to turn these same ideas toward improving our own teaching practices. 
To do this will require a shift in our thinking and activities as we organise academic work in different ways. We already have the concepts of inquiry and reflective practice firmly embedded and accepted in a limited way, and these skills are critical to action research which provides a simple method that can be adopted by any university academic. However, research into teaching is currently a marginal activity and still not quite respectable, and we must work out how to do this in a manner that not only benefits the individual or collaborative group, but is of such quality that the work is also relevant to a wider academic community and society. Action research accounts ought to stand alongside other forms of research and, importantly, be recognised as having utility for others. The practitioner who uses action research methods to investigate their practices will not only learn to the benefit of themselves and their students, but if done well it can also contribute to a theory of higher education, just as it will draw on previously published theories and integrate knowledge in a scholarly way.

In fact, action research for enhancing university teaching may only become acceptable when its practitioners legitimise their work by contributing to the wider research community. It must not be driven by self-interest only, but also by the needs of others. Such an ontological turn is about re-examining our values and it will be interesting to see how the AKEPT scheme for practitioner researchers succeeds in convincing academics to think again.

\section{REFERENCES}

Anderson, C. W. (1993). Prescribing the life of the mind: An essay on the purposes of the university, the aims of liberal education, the competence of citizens, and the cultivation of practical reason. Wisconsin: The University of Wisconsin Press.

Barnett, R. (1990). The idea of higher education. Buckingham: Open University Press.

Barnett, R. (2003). Beyond all reason: Living with ideology in the university. Buckingham: Open University Press.

Boshier, R. (2009). Why is the scholarship of teaching such a hard sell? Higher Education Research and Development, 28(1), $1-15$.

Boyer, E. L. (1990). Scholarship reconsidered: Priorities of the professoriate. Princeton, NJ: The Carnegie Foundation for the Advancement of Teaching. 
Brew, A. (2010). Imperatives and challenges in integrating teaching and research. Higher Education Research and Development, 29(2), 139-150.

Carr, W., \& Kemmis, S. (1986). Becoming critical. Education, knowledge and action research. London: The Falmer Press.

Dewey, J. (1910). How we think. Boston: D.C. Heath Publishers.

Dewey, J. (1938). Logic: The theory of inquiry. NY: Henry Holt and Company.

Harland, T., \& Staniforth, D. (2000) Action research: A culturally acceptable path to profesional learning for university teachers? Educational Action Research, 8(3), 501-516.

Harland, T. (2009). The university, neoliberal reform and the liberal educational ideal. In M. Tight, J. Huisman, K. H Mok \& C. C. Morphew (Eds.), The Routledge International Handbook of Higher Education. London: Routledge.

Harland, T., \& Staniforth, D. (2009). A family of strangers: The fragmented nature of academic development. Teaching in Higher Education, 13(6), 669-678.

Konting, M. M., Singh, E. K., \& Idris, Z. (2009). Transforming higher education in Malaysia: The AKEPT's teaching and learning initiatives. International Conference on Education and New Learning Technologies (EDULEARN09).

Lewin, K. (1946). Action research and minority problems. Journal of Social Issues, 2, 34-46.

Jenkins, A., Breen, R., \& Lindsay, R. (2003). Re-shaping higher education: Linking teaching and research. London: Routledge Falmer.

Schön, D. (1987). Educating the reflective practitioner. San Francisco: Jossey-Bass Publishers.

Schön, D. (1992). The theory of inquiry: Dewey's legacy to education. Curriculum Inquiry, 22(2), 119-139.

Schön, D. (1995). Knowing-in-action. The new scholarship requires a new epistemology. Change, November/December, 27-34.

Seldin, P. (2004). The teaching portfolio (3rd ed.). Bolton, MA: Anker.

Stenhouse, L. (1980). The study of samples and the study of cases. British of Educational Research Journal, 6(1), 1-6.

Stenhouse, L. (1981). What counts as research? British Journal of Educational Studies, 14(2), 103-114. 